\title{
How is Mortgage Lending Influencing the Economic Growth in Albania
}

\author{
Iris Shahini \\ Alpha Bank \\ Tirane, Albania
}

\begin{abstract}
Banks in Albania have been playing an important role in providing credit to the households especially to the housing sector and thereby contributing to the aggregate demand in the sector. Moreover, Albanian banks also extend various types of loans against the individuals and corporate before the financial crisis. After the crisis the banks become more restricted due to increase of non-performing loans as well as the macroeconomic volatility which is higher in emerging economies like Albania. In my study I will focus on the influence of mortgage loans and nonperforming loans in the country economic growth during the interval 2008-2013 that corresponds with the after crisis period.
\end{abstract}

Keywords - economic growth, housing loans, housing market, nonperforming loans, GDP

\section{INTRODUCTION}

Banking system stability is important for the development of a country. The bank's role can be said to be a catalyst for economic growth. The activity and performance of the banking industry is an indicator of financial stability. The rate at which banks finance public productive activities accelerates economic growth and ensures long-term sustainability. First of all, mortgage loans represent the main part of retail loans. Secondly, the default in payments of mortgage loans do not impact only the owners of the properties but also banks that use these properties as collaterals. Moreover, through the second market products as MBS, risk is spread all over the economy. During the last years the impact of financial crisis shrink the willingness of banks to lend and made them more conservative in terms of credit standards. Up to the year 2008, banks especially the Greek once, were much more aggressive in lending of housing loans mainly in foreign currency. The financial crisis lead to the deprecation of Albanian currency towards EUR and Albanian banks started to orient the customers to have the loan in the same currency as their incomes in order to avoid the exchange rate risk. On 2009 the loan in euro composed $72 \%$ of the total loan portfolio. As per constructors, there are the banks that supply the economy with money and the decrease in selling of properties is a consequence of loan supply from banks side considering that the individuals that buy an apartment in cash are very few in number. The aim of this study centered on how the mortgage loans and nonperforming loans influence the economic growth in Albania. The period under consideration is the one corresponding with the financial crisis 2008-2013.

\section{LITERATURE REVIEW}

As personal income rises or the burden of debt declines, the demand for mortgage funds should increase. In the models on credit demand, real GDP, prices and interest rates are commonly the explanatory variables, although there is no "standard" model which would be widely used. However, modeling and estimation techniques in this area are complicated due to difficulties with separating demand side effects from supply side effects (see e.g. Rajan 1994). Empirically, the relationship between credit and current economic activity is well founded in Hofmann (2001) documents in 16 industrialized countries. The annual rate of change in real credit is closely related to that of real GDP Erjona Suljoti and Gent Hashorva (2011) studied the impact of mortgage loans in the residential prices, GDP per capita and interest rate in the demand for mortgage loans. The correlation between the independed variables and the depended one was very strong for the period 1998-2010. GDP per capita and residential prices are positively correlated with the demand of housing loans from individuals and interest rate is negatively correlated. Festic, Kavkler, Repina (2011) confirmed that changes in macroeconomic conditions are translated into changes in the quality of bank loan portfolios.

\subsection{Mortgage market and mortgage lending in} Albania

The dwelling market as well as the housing loan market in Albania has experienced many changes. The developments in these two markets can be divided in two time periods. During the first period 2000-2007 a very fast development of dwelling market and mortgage loans market has occurred. Meanwhile during the period 2008-2012 the increase in both markets has slowed down due to the global financial crisis and the slow-down of economic activity in Albania( see table 1 and 2).

Table 1. Economic growth in Albania (annual \%)

\begin{tabular}{|c|c|c|c|c|c|c|}
\hline $\mathbf{2 0 0 7}$ & $\mathbf{2 0 0 8}$ & $\mathbf{2 0 0 9}$ & $\mathbf{2 0 1 0}$ & $\mathbf{2 0 1 1}$ & $\mathbf{2 0 1 2}$ & $\mathbf{2 0 1 3}$ \\
\hline 5.9 & 7.5 & 3.3 & 3.8 & 3.1 & 1.62 & 0.4 \\
\hline
\end{tabular}

Source: INSTAT

Table 2: GDP/Capita in PPS

\begin{tabular}{|c|c|c|c|c|c|c|}
\hline $\mathbf{2 0 0 7}$ & $\mathbf{2 0 0 8}$ & $\mathbf{2 0 0 9}$ & $\mathbf{2 0 1 0}$ & $\mathbf{2 0 1 1}$ & $\mathbf{2 0 1 2}$ & $\mathbf{2 0 1 3}$ \\
\hline 23 & 26 & 28 & 27 & 30 & 30 & 30 \\
\hline
\end{tabular}

Source: Eurostat 
Even though it was not expected to be so fast, the crisis in the real estate market had started based on the official data of Bank of Albania and real estate agencies which were not satisfied with the transactions of last period in the real estate market in 2008. Based on the statistic that these agencies published in the "Albania" newspaper it was obvious that the demand for house purchase from emigrants has been considerably decreased. Such evidence has been confirmed also from the Bank of Albania. The decrease for housing purchase from individuals has started since 2008 due to the difficult financial situation and low remittances from emigrants. Another factor influencing in the tendency of individuals to purchase a house is the loan financing. In 2008 banks started to be more restricted in lending mainly due to the increase of non- performing loans. The difficulty in having a loan will influence the market considering that the construction sector and industry absorb $77 \%$ of the total loan portfolio which is used to finance the investments in real estate. While the increase in house price was justified with the increase of construction materials as per BOA report. The macroeconomic environment, business difficulties as well as the restrictive decisions of $\mathrm{BOA}$ towards the second level banks have influenced in the decrease of loan supply. In Albania the individuals buy a house for living purpose rather than investment one so the decrease demand is much lower than in Europe or USA. Almost $70 \%$ of purchases are done through bank financing and only $30 \%$ are done in cash.

\subsection{The trend of housing loans in Albania}

During the period 2004-2007 the mortgage loans portfolio has experienced a high increase with an average annual increase of $65 \%$. Such a positive trend has been sustained from the banking system development and economic growth of the period. It was created a stratum with average income having the possibility to meet the monthly obligations towards banks. On the same time the privatization of ex Saving Bank occurred, the biggest bank in Albania, named Raiffeissen Bank which gave liquidity to the market and stimulated banks to announce a new product, the "mortgage Loan". On the supply side of mortgage loans, banks used to gain market share by offering very convenience products. Many banks used the mortgage loan to diversify their loan portfolio in terms of quality and cost of funds. The willingness of banks to develop this market segment went along with the increase of individuals demand to be financed. Such an increase was due to the increase of housing prices during the years 2004-2007 which was not affordable to be paid in cash from the buyers. During this period the housing price were about $50 \%$ higher than in 2004. The mortgage loan portfolio for individuals composes almost $20 \%$ of the banking system loans portfolio. The product for housing financing may have a fix interest rate or a floating one. The interest rates also differ as per product currency. In general, most of the loans financing are in euro with floating interest rates. In any case some hybrid products have resulted to be successful in the market by having a fix interest rate for the first 2-5 years and floating for the remaining period. Banks in Albania finance up to $80 \%$ of the collateral market value and the tenor vary from 5 to 30 years. The demand for housing loans on 2007 and beginning of 2008 was higher than the demand of individuals for consumer loans. Despite the necessity of individuals to be financed for house purchase other factors that have positively contributed in the demand for housing loans were: the developments in real estate market, consumer's confidence and credit policies applied from banks. Credit policies standards have been somehow tighten on the fourth quarter of 2009 through increasing the spread for the high risk loans, following the same trend as European banks. The demand in the same time decreased although the new buildings constructed were 1,021 in total. New disbursements during the year 2009 suffered a considerable decrease from 35,948 million ALL in 2008 to 15,146 million ALL. Although 2010 the credit policy standards in general were tightened, for housing loans they became more soothing compared with the year 2009. Two main factors that make banks to be conservative in lending are the non performing loans and low income of individuals

\subsection{Nonperforming loans in the banking system}

The increase of nonperforming loans in the banking system has been an important factor in the restriction of loan procedures for individuals and even for businesses.

Credit risk dominates the risk profile regardless the careful credit process of banks. The credit risk originating from the loan portfolio of banks remains the main risk with a direct effect on the financial stability of the banking sector. Regardless the contraction in crediting and the recent tendencies of the banks to deploy a great amount of their funds in safe actives, the credit risk remains dominant in the risks profile of the banking sector even during the second half of year 2013. During the second half of year 2012, nonperforming loans in the banking sector increased in 130 billion ALL, from 121 billion ALL in the first half and 160 billion ALL in the second half of 2011. Nevertheless, the pace of growth of nonperforming loans has slowed down from quarter to quarter. There was a slight improvement in the loans stock in the last quarter of the year with $0.95 \%$. The deceleration of nonperforming loans reflects the increase of the bank's efforts to collect money. At the end of 2012, the ratio of nonperforming loans to the total loans increased from $21.1 \%$ to $22.5 \%$ in the first half of 2012 and from $18.8 \%$ in the same period of the previous year. The highest amount of nonperforming loans was on the second quarter of 2013 with a rate of $24.34 \%$ in the third quarter and $23.22 \%$ in the last quarter of 2013.

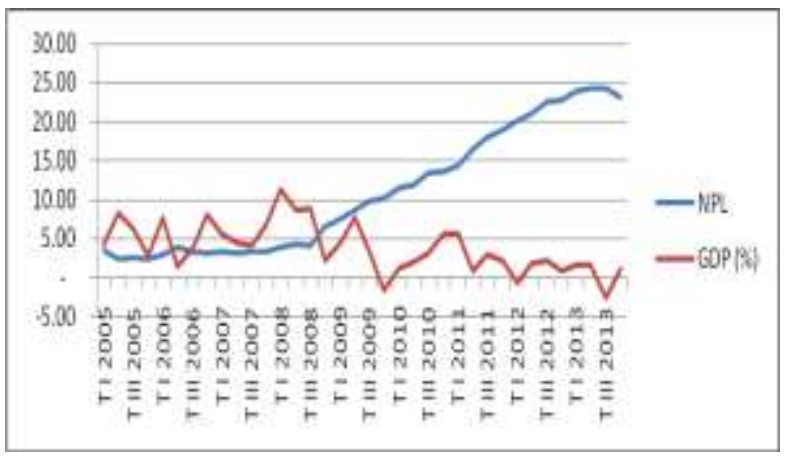

Figure 1: The trend of NPL and GDP ( in \%) 


\section{METHODOLOGY AND DATA}

The purpose of this paper is to describe the relation between the mortgage loans and nonperforming loans as a dependent variable and the economic growth as in depended variable. The period taken in consideration is 2008 up to 2013 corresponding with the beginning of the financial crisis. The data have been taken from different sources as Bank of Albania , Ministry of Finance, Albanian Association of banks etc. The time series of these data are on quarterly basis.

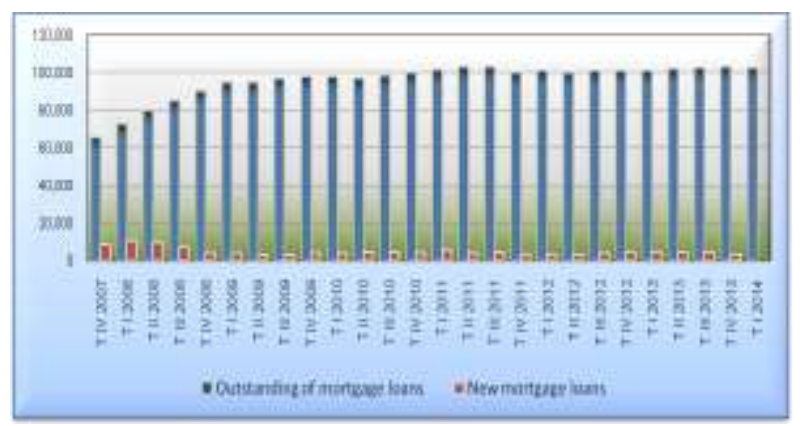

Figure 2: Mortgage loans in million ALL

The Assessed Model

$\mathrm{YNS}=\mathrm{c}+\mathrm{b} 1 \log (\mathrm{YD})+\mathrm{b} 2 \mathrm{NPLN}$

Where:

YNS- is the economic growth

YD -new mortgage loans

NPLN-the rate of nonperforming loans

YNS $=-0.37+0.05 \log ($ YD) -0.002 NPLN

\begin{tabular}{lrrrr}
\hline \hline \multicolumn{1}{c}{ Variable } & Coefficient & Std. Error & t-Statistic & Prob. \\
\hline \hline \multicolumn{1}{c}{ C } & -0.374677 & 0.154648 & -2.422773 & 0.0245 \\
LOG(YD) & 0.051494 & 0.017470 & 2.947488 & 0.0077 \\
NPLN & -0.002080 & 0.000779 & -2.669971 & 0.0143 \\
\hline \hline R-squared & 0.613071 & Mean dependent var & 0.031250 \\
Adjusted R-squared & 0.576221 & S.D. dependent var & 0.034302 \\
S.E. of regression & 0.022330 & Alaike info criterion & -4.649298 \\
Sum squared resid & 0.010471 & Schwarz criterion & -4.502042 \\
Log likelihood & 58.79158 & Hannan-Quinn criter. & -4.610231 \\
F-statistic & 16.63679 & Durbin-Watson stat & 1.888561 \\
Prob(F-statistic) & 0.000047 & & \\
\hline \hline
\end{tabular}

Table 3: Results of the assessed model (author calculations)

Based on the above calculations we conclude that the regression coefficients $\mathrm{b} 1$ and $\mathrm{b} 2$ are statistically important considering that the probabilities are lower than 0.05 .

b1 shows that when mortgage loans increase by $1 \%$ the economic growth increase by $0.0005 \%$ by having constant the NPLN.

b2 shows that when NPLN increase by one unit the economic growth decrease by 0.002 units by having constant the new mortgage loans.
The $r^{2}$ value of 0.57 means approximately 57 percent of the variation in the YNS is explained by variation in the YD and NPLN

Hhypothesis testing:

To test the significance of the model we will rise the hypothesis based in the Fisher index with the level of significance $\alpha=0.05$ and (k-1), (n-k) df , it is often called the critical $F$ value at $\alpha / 2$ level of significance.

If $\mathrm{Ff}>\mathrm{Fkr}$ then the hypothesis (H0) is rejected, and the assets model is statistically significant

For our model we postulate that :

H0: The assessed model is not statistically significant

Ha: The assessed model is statistically significant

Performing the calculations with E-Views we reach to the conclusion that factice value of Fisher (Ff) is 16.63 while the critic value for $F(n-k)(k-1)=4.3$ ( $5 \%$ significance)

We concluding that the assessed model is statistically significant thus the Ho hypothesis is rejected.

Autocorrelation

To test the presence of the autocorrelation we will use the Durbin Watson test.

$$
d=\frac{\sum_{t=2}^{t=n}\left(\hat{u}_{t}-\hat{u}_{t-1}\right)^{2}}{\sum_{t=1}^{t=n} \hat{u}_{t}^{2}}
$$

In our model the $\mathrm{d}$ value 1.88 is around 2 , which would suggest that there is no autocorrelation in such model. Another test performed is the LM test for the serial correlation. Based on the below table we can conclude that there is no presence of the serial correlation in our model

Breusch-Godfrey Serial Correlation LM Test.

\begin{tabular}{llll}
\hline \hline F-statistic & 1.835905 & Prob. F(2,19) & 0.1867 \\
Obs:R-squared & 3.886917 & Prob. Chi-Square(2) & 0.1432 \\
\hline \hline
\end{tabular}

Table 4. Results of the LM test (author calculations)

\section{Heteroscedasticity Test}

An important assumption of the classical linear regression model is that the disturbances term $u i$ appearing in the population regression function are homoscedastic; that is, they all have the same variance. Symbolically:

$$
\boldsymbol{E}\left(u_{i}^{2}\right)=\sigma^{2} \quad i=1,2, \ldots, n \mid
$$

$\underline{\text { For our model we postulate that }}$

Ho: No presence of heteroscedasticity Ha: Presence of heteroscedasticity 
Based of the Arch's heteroscedasticity Test below the estimated model is insignificant and also the coefficients of the model considering the respective probabilities higher than 0.05 . We conclude that in our model the heteroscedasticity is not present.

\section{Hotetrolkedasticity Test ARCH}

\begin{tabular}{llll}
\hline \hline F-statistic & 2.613473 & Prob. F(1,21) & 0.1209 \\
Obs $*$ R-squared & 2.545576 & Prob. Chi-Square(1) & 0.1106 \\
\hline
\end{tabular}

Table 5: The results of heteroskedasticity test (author calculations)

\section{Jarque-Bera (JB) Test of Normality}

The JB test of normality is based on the OLS residuals.

$$
\mathrm{JB}=n\left[\frac{S^{2}}{6}+\frac{(K-3)^{2}}{24}\right]
$$

where $\mathrm{n}=$ sample size, $\mathrm{S}=$ skewness coefficient, and $\mathrm{K}=$ kurtosis coefficient. For a normally distributed variable, $\mathrm{S}=0$ and $\mathrm{K}=3$. Therefore, the JB test of normality is a test of the joint hypothesis that $S$ and $\mathrm{K}$ are 0 and 3, respectively. In that case the value of the JB statistic is expected to be 0 . If the computed $p$ value of the JB statistic in an application is sufficiently low, which will happen if the value of the statistic is very different from 0 , one can reject the hypothesis that the residuals are normally distributed. But if the $p$ value is reasonably high, which will happen if the value of the statistic is close to zero, we do not reject the normality assumption. Application of the Jarque-Bera test shows that the JB statistic is about 0.273405 , and the probability of obtaining such a statistic under the normality assumption is about $87 \%$. Therefore, we do not reject the hypothesis that the error terms are normally distributed.

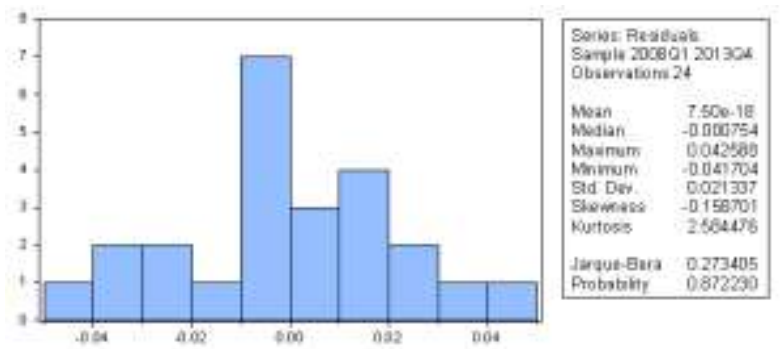

Figure 3: Normality test of residuals series (author calculations)

\section{CONCLUSIONS}

The purpose of this study is to analyze how is housing loans and NPL influencing the economic growth of Albania. The analyze has taken in consideration two factors the new mortgage disbursements and NPL rate as the independent variable and the economic growth as the dependent variable. To treat the problem empirically it was used the lin-log regression model. For the period taken into consideration 2008-2013 corresponding with the financial crises, we reached in the conclusion that the new housing loans has a strong positive relation with the economic growth and the rate of NPL has negative relation with the economic growth.

In the last years the demand for housing loans in Albania, decreased in parallel with the decrease of the supply form banks side corresponding to the increase in the non performing loans.

On the other hand the prices suffered a low decrease even though the stock of unsold properties increases.

The slowdown in loans reflects decrease in the demand side from individuals.

Credit Standards and Loan demand in Albania followed almost the same trend as those of Eurozone during this period.

\section{ACKNOWLEDGMENTS}

This paper is part of my $\mathrm{PhD}$ thesis which for I would like to thanks all my colleagues and my professors who advised and helped me to progress in my research.

\section{REFERENCES}

[1] Berger, Allen N. \& Humphry De Young, "Problem Loans and Commercial Banks", Journal of Banking and Finance, Vol. 21, 1997

[2] Boleat, M. (2008) - Housing Development and Housing Finance in Britain - Some lessons for emerging markets, Housing Finance International March 2008, Vol. 22 Issue 3, pp 53-58

[3] Diamond, D.B. and M. Lea (1993) - The Efficiency of Housing Finance Systems: An international comparison, Housing Finance International September 1993, Vol.8 Issue 1, pp 36-43.

[4] Ergungor, O.E. (2008) - Covered Bonds: A new way to fund Residential Mortgages, Federal Reserve Bank of Cleveland Economic Commentary, July 2008.

[5] Favara, G. (2003) - An Empirical Reassessment of the Relationship between Finance and Growth, IMF Working Paper WP/03/123.

[6] Fischer, S. (2004) - IMF Essays from a time of Crisis: The International Financial System, Stabilization and Development, Cambridge, MA: MIT Press, 2004.

[7] Veronica C. Warnock Francis E. Warnock (2007) markets and housing finance (NEBER Paper No.13081)

[8] Albanian Association of Banks, Credit to the Economy by purpose statistical data 2008-2013 http://www.aab.al

[9] Instat statistics http://www.instat.gov.al 